\title{
Korero Rakau
}

\section{Wiremu Woodard}

\author{
INDIGENOUS THERAPIST
}

\begin{abstract}
This article is an extract taken from a panel presentation by Waka Oranga (Māori Psychotherapists and Health Practitioners Collective), Māori Spirituality and Holistic Psychotherapy, at the 2016 New Zealand Association of Psychotherapists' Annual Conference at Ahuriri, Napier, Aotearoa, New Zealand. The article considers our symbiotic nature and the importance of metaphor in defining (and determining) reality. The article argues that metaphors reflect implicit epistemological and ontological assumptions and that metaphors particular to a culture/society will determine the ecological footprint of that culture/society. Following this logic, the article concludes by asserting that the current ecological catastrophe confronting humanity and the planet is directly related to predominant positivistic and reductionist paradigms and their attending metaphors which separate and fragment the world into consumable commodities.
\end{abstract}

\section{Waitara}

He kapenga mai tēnei tuhinga mai i tētahi rārangi kauhautanga a Waka Oranga (Kaiwhakaora Hinengaro me te Huinga Kaimahi Hauora Māori), Wairua Māori me te Whakaoranga Hinengaro Whānui i te Hui ā tau a te Huinga Kaiwhakaora Hinengaro o Aotearoa i Ahuriri, Napier, Aotearoa, Niu Tīreni. Ka whakaarohia ake tō tātau āhua piritahitanga me te whai tikanga o te whakataukì hai whakaahua (whakatau hoki) i te ao nei. E tautohe ana tēnei tuhinga he whakaaturanga whakahau tā te whakataukī ā, ka kitea te rite o te noho a te hāpori pērā i aua whakataukī. Mai i tēnei whakaruapapanga, ka whakahauhia i te whakamutunga he here tō ngā aituā taupuhi taiao kai mua i te ao me te tangata ki ngā tauira tōrunga, tango haora me ngā kīanga whai ake e wehe nei e wāwāhi nei i te ao hai taonga hokohoko.

Keywords: Indigenous; metaphor; Māori; tree communication; Matariki

\section{Introduction:}

Tirohia atu nei ngā whetū

Me ko Matariki e ārau ana

He hōmai tau i nga mahara
I gaze up at the stars,

And the Pleiades are

Gathered together

Woodard, W. (2016). Korero rakau. Ata: Journal of Psychotherapy Aotearoa New Zealand, 20(1), 35-45. DOI:10.9791/ ajpanz.2016.04 ( ) New Zealand Association of Psychotherapists Inc. 
E kohi nei whakarerea atu Nā te roimata ka hua riringi Tāheke ware kai aku kamo
Which gives

Rise to many thoughts

That well up within, and freely,

Do the tears pour forth

And flow shamelessly from mine eye.

(Mihi-Ki-Te-Kapua, as cited in Ngata, 2007, pp.120-123)

The raising of Puanga (Rigel) and later Matariki (Pleiades) in the north east of the Southern Hemisphere herald mid-winter, a time of re-membering and a celebration of humanity's deep ecological selves, inseparable from the planet and cosmos of which we are a part. The celebration of Matariki is a reminder that we, like the world around us, move through a cycle of birth and death, dormancy and regrowth. In the depth of winter, the sap withdraws to nourish the heartwood through the lean cold months. Matariki signals the completion of the harvest, and a time to gather around the fires of our imagination to contemplate, explore, and refine the narratives (metaphors) that give the world around us meaning. This is an essential process of evaluating Indigenous knowledge systems, based on intimate connections with the cycles of the world and our cosmos.

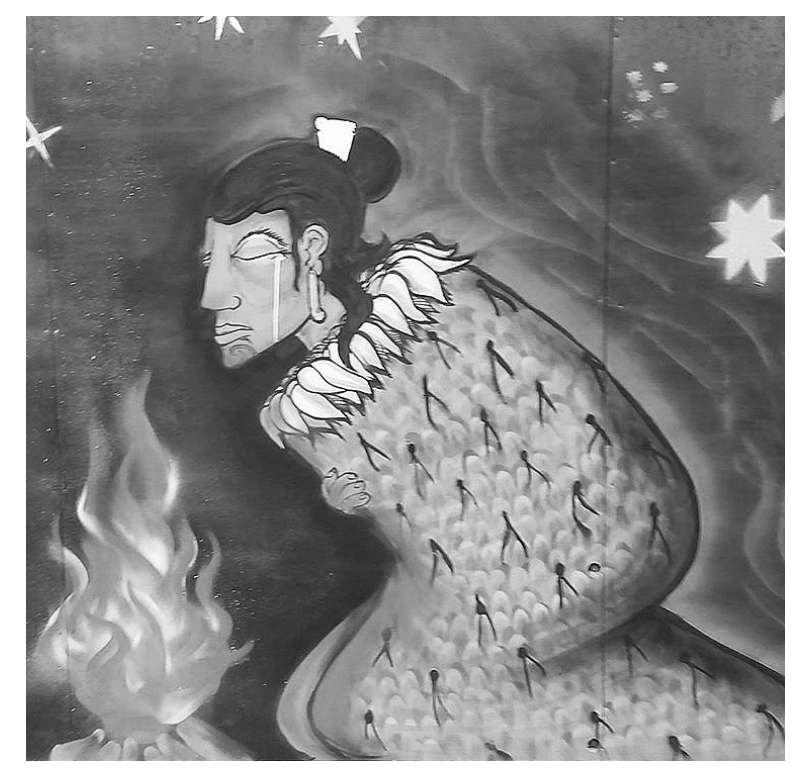

Figure. 1 Matariki street mural outside Auckland City Library by Numa Mackenzie (2016).

A beautiful and un-supposing example of this Indigenous knowing was a story that Matua Haare shared with us at our Waka Oranga presentation at the 2016 conference. He began with a kōrero about his kuia, Nan Wairemana, talking to the plants and fruit trees in her 


\section{WIREMU WOODARD}

garden, describing her verdant and abundant garden. Not long after his kuia died, the garden fell into dis(re)pair, wilted, and perished.

This article is a small exploration of the symbiotic relationship inherent in Indigenous paradigms and philosophies as we approach Matariki, a celebration of our deep relationship with the Earth and each other.

I would like to begin this exploration by explicitly stating my belief that the plants in Nan Wairemana's garden died of a broken heart; they were lonely and ceased to flourish. There are multiple interconnected possible explanations why this garden failed, however I am intentionally pointing to (with the use of anthropomorphic language) two dual phenomenon. First, the story of the garden provides an example of the primary relationship between a person and his/her ecology, where the person is an integral part of an eco-system, effectively becoming a single entity. The second associated theme concerns the use of language, our ability to describe and imagine ourselves within and a part of multiple symbiotic relationships. The metaphors Indigenous cultures use to give meaning and to describe reality, far from being "just" anthropomorphic, reflect our inherent epistemology - a deep ecological self-awareness.

This symbiotic ontology particular to Indigenous epistemologies has been relentlessly attacked by the rise of rationalism and Cartesian thinking, which splits off self and other - creating, defining and describing the universe as a machine mechanism, creating a technocratic society where experience and reality are reduced to its smallest components (Gains \& Davis-Floyd, 2004). The rise of the rational imperative has accompanied Western imperialism and the domination and subjugation of other ways of knowing and relating to the world. However, interestingly (and maybe ironically), emerging scientific research is increasingly pointing to and re-orienting us towards the interconnected reality of our shared universe.

\section{Trees and Plants Talk to Each Other}

Biologists are aware that plants use a range of methods to communicate. Early research discovered that plants communicate chemically by releasing volatile organic compounds (VOCs) into the air to warn neighbouring plants of predators or adverse conditions such as impending drought. Halopainen (as cited in Cossins, 2014) explained this method of communication, "individual compounds are the words and these words are combined to make specific sentences” (p. 5).

As well as communicating using VOCs, biologists suspect that plants also communicate below ground using highly sophisticated common mycelia (fungi) networks. In 2009, Babikova and colleagues (2009) infested bean plants with aphids and prevented the plants from emitting VOCs (by wrapping the leaves in plastic). The infested bean plants exposed to aphid attack ingeniously released VOCs to alert neighbouring bean plants to release VOCs that both repel aphids and attract aphid hunting wasps. The researchers found that only plants with a mycorrhizal (subterranean fungi) connection to the infested plant were repellent to aphids and attractive to wasps, demonstrating not only terrestrial but also subterranean communication systems.

The mycorrhizal network is intricate and complex and we are only just beginning to 
glimpse the extent and level of subterranean communication. Basically, subterranean networks of fungi connected to root systems of plants/trees sell nitrogen and phosphorous to the plant in return for carbon (produced through photosynthesis and transported to the roots) which is then exported and traded with other trees. Initially, research focused on common mycorrhizal networks as biological market places (a swap-meet for carbon). More recent research shows how these subterranean networks are also used as communication systems. When Klein, Siegwolf and Körner (2016) tracked Carbon-13, a form of carbon, in a stand of Norwegian spruce trees, they found that the spruce trees not only exchanged $\mathrm{C}-13$ with neighbouring spruce trees, but they also exchanged $\mathrm{C}-13$ with trees of other species in a bi-directional manner. It appears that there is a huge level of interchange between trees and one hectare of forest can pull down and exchange a quarter of a tonne of carbon per day.

Our perception of trees as unresponsive and uncommunicative organisms is beginning to change. Research is drawing a picture of trees as less like individuals and more as communal beings - working together in networks, sharing resources, and engaging in conversations, including warning each other of attack or impending drought (McGrane, 2016). Peter Wolenberg in his book, The Hidden Life of Trees (2016), described trees as social beings who can count, learn, and remember; they nurse sick neighbours, warn each other of danger, and, for reasons unknown, keep the stumps of long-felled companions alive for centuries by feeding them sugar solution through their roots (Wolenberg, as cited in McGrane, 2016). Increasingly researchers are beginning to appreciate the relationships between human and tree chemistry, especially in the areas of co-evolution, pollution, and emissions (Briggs, 2009; Cumo, 2016; Van der Merwe, 2005). As we begin to recognise and learn about the intricate and sophisticated ecology of treeness, we are also beginning to understand and recognise our own ecology.

Researchers have found that trees talk to each other; it is not so hard to imagine the range of communication that might be possible between human beings and trees/other nonhuman beings, that we are in fact symbiotic organisms intricately connected within complementary eco-systems. The story of Nan Wairemana's garden is illustrative of an ecological consciousness which permeates Indigenous ontologies and can be found in every facet of Indigenous lives. This ecological self is easily identifiable in Indigenous narratives and ritual processes.

For example, in Māori traditions, after Tāne-mahuta (in the form of a giant kauri) separated Papatūānuku (Earth Mother) and Rangi-nui (Sky Father), Tane proceeded to cover the Earth with life: trees, birds, insects, and, later, human beings. In this narrative, trees and plants are our tuākana, or elder siblings. It is interesting to note, that all plants, fungi, and animals share the same genetic evolutionary beginnings, and that terrestrial plants evolved over 470 million years ago (Cumo, 2016) and today plants and humans still share around $17-30 \%$ of the same genetic material (Tattersall, DeSalle, \& Wynne, 2007).

In a recent lecture at Auckland University, Dr Yellow Bird (2016) reflected on aspects of the Holy Cedar Ceremony of the Arikara people of North Dakota, U.S.A. In late summer or early autumn Arikara peoples sing in praise and honour to a holy cedar tree (a sacred deity of the Arikara peoples), offering gifts and receiving ceremonial blessings. The tree is referred to as Atika Waruh Ti (Holy Grandmother). During the ceremony an Arikara holy man sings 


\section{WIREMU WOODARD}

to the cedar, "The Creator created thee to have a place in the Universe; to stand and adorn Mother Earth; the cedar tree is a tree of long life. The Creator made thee to endure the longest life." These processes may occur for up to 90 days.

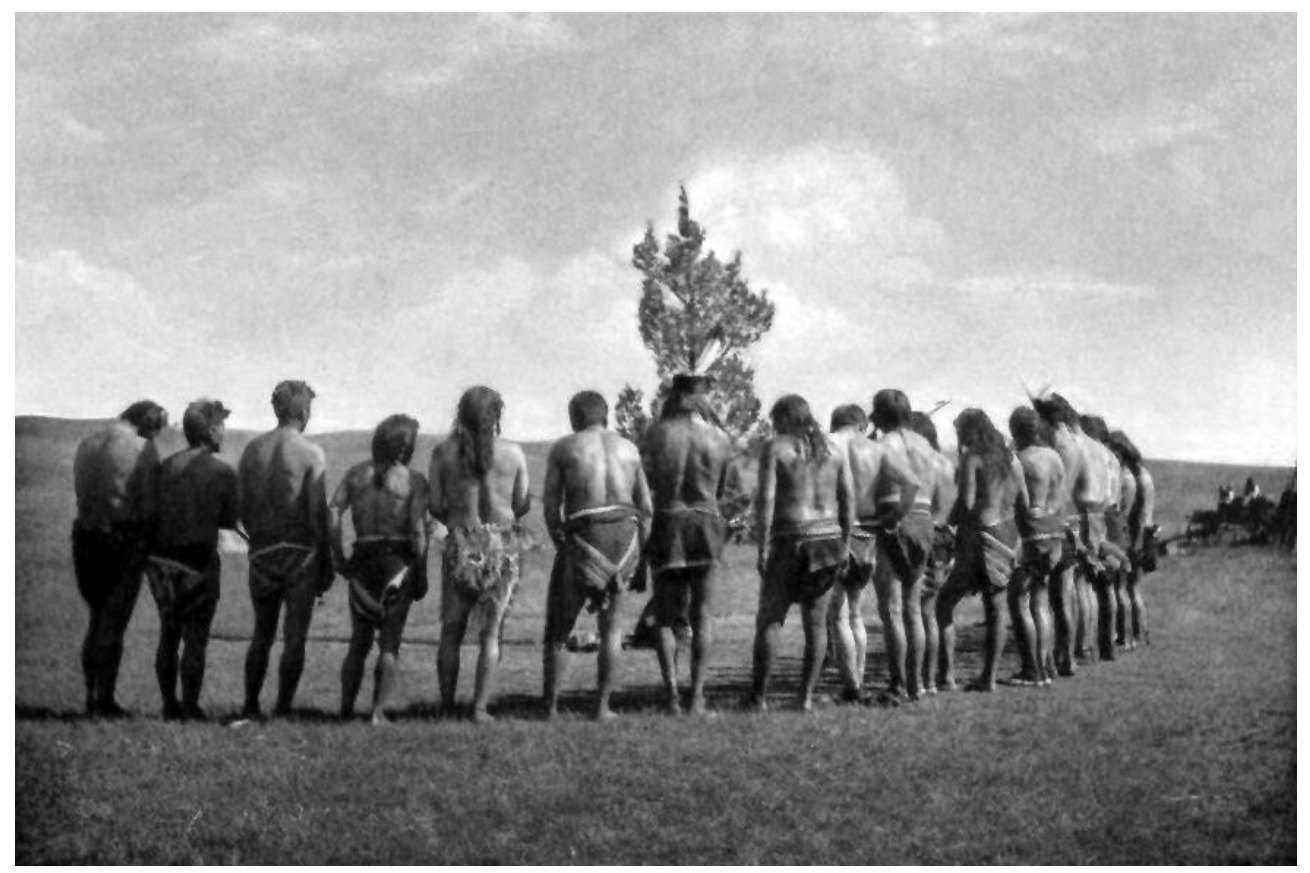

Figure 2. Arikara Holy Cedar Ceremony. This photo has been reproduced with Dr Yellow Bird's blessing.

Linking neuroscience and Indigenous ontologies, Dr Yellow Bird (2016) described the increased sensitivity of the human brain which occurs during these ritual and meditative processes. Through this heightened neural sensitivity, Dr Yellow Bird described the resulting ability of the Arikara people to sense subtle emanations (communications) between tree and person.

The long period of singing and the intensive offering of prayers to the Holy Grandmother by the supplicants/petitioners would enable them to experience a sense of oneness with the Holy Grandmother and all living things because of reduced activity in the parietal lobes, which results in a blurring of the perceived lines between the person and other objects ( Dr Yellow Bird, personal communication, September 21, 2016).

More information on the neuroscience of this phenomena is available at www.theatlantic. com/health/archive/2014/o6/what-happens-to-brains-during-spiritual-experiences/361882/.

Davis (2003) described the complex preparation of ayahuasca in ritual ceremonies by the Cofan people of the Sucumbíos Province, Northeast Ecuador, and Southern Colombia. When ayahuasca is combined with psychtia viridis, it forms a potent psychoactive drug. Interestingly the tryptamines active in psychtia viridis are only effective when combined 
with ayahuasca, whose monoamine oxidase inhibitors stop the human gut from denaturing the tryptamines. Davis invited us to ponder, how did the Cofan discover, in a flora of 8o,000 species of vascular plants, two morphologically unrelated plants that when combined create an echogenic miracle? Trial and error? The sheer number of plant species with varying chemical properties make the probability of discovering the precise combination of chemical compounds by trial and error alone highly improbable, almost impossible. But, Davis (2003) said, if you ask the Cofan they say, "The plants talk to us."

Well, what does that mean? This tribe, the Cofan, has 17 varieties of ayahuasca, all of which they distinguish a great distance in the forest, all of which are referable to our eye as one species. And then you ask them how they establish their taxonomy and they say, "I thought you knew something about plants. I mean, don't you know anything?" And I said, "No." Well, it turns out you take each of the 17 varieties in the night of a full moon, and it sings to you in a different key. Now, that's not going to get you a Ph.D. at Harvard, but it's a lot more interesting than counting stamens!

$(13: 40-14: 12)$

Indigenous cultures do not have a romantic self-conscious conception of "being close to the land”. Instead, what is intrinsic in Indigenous paradigms/epistemologies is that the land is alive, the land and people are engaged in a living dynamic relationship, where the world is embraced and transformed through the brilliance of the human mind/imagination; reality is the expression of a cosmic living universe (Davis, 2009). While surviving Indigenous cultures may be the custodians of this particular ecological self, I suggest that these ancient knowledge systems and paradigms are our shared common inheritance. Our most recognisable modern ancestors began exploring all the corners of this planet 500,000200,000 years ago (Wells, 2002). Dental records show that 14 million years before that we separated out from our closest primate brothers and sisters (Schwartz \& Tattersall, 2005). It has only been in the last 10,000 years that we began to cultivate crops, with our modern industrial era only occurring in the last 300 years. For $99 \%$ of our histories we have been hunter-gatherer societies. We share hundreds of thousands of years of history (if not millions) based on our interdependent reciprocal relationship with the world we live in and embody. As Arabena (2015) said, we are Indigenous to the universe. However, this article argues that metaphor gives the universe shape and colour, reflecting our central epistemologies. So, is the universe the interaction of atomic particles spinning through space and time? Or, are we born from the union of a comet seduced from the heavens by a creature of mist? Far from being mere differences in descriptive prose, the gulf between these two narratives represents the degree of separation between ontological realities inherent in each of these epistemologies. This degree of separation is replicated at every level, that is, the narratives that our cultures and societies use to describe, contextualise, and position ourselves in the world/universe also pattern and structure identity and self. Varying theorists (for example, see Dalal, 2002; Elias, 1976, 2010; Erikson, 1966; Fanon, 1982; Fonagy, 2001; Foulkes, 1948; Holmes, 1993; Hume, 1748) have suggested that "we", society and culture, determine the "I", rather than the conventional understanding of "we" (society) being formed from the grouping of many pre-existing (essential) "I"s. These theorists suggest that 


\section{WIREMU WOODARD}

the subjective experience of "self" is constructed through the internalisation of categories, attitudes, and behaviours of the culture and society we are born into. To this end, the metaphors we use not only give meaning and explain our experiences, revealing our underlying assumptions, but they also ultimately determine our reality (King, 2003; Lakoff \& Johnson, 1980) and, in particular, the metaphors that we use will determine the ecological footprint we leave on this planet. Davis (2009) surmised that;

A child raised to believe that a mountain is the abode of a protective spirit will be a profoundly different human being from a youth brought up to believe that a mountain is simply a pile of inert ore waiting to be mined. A boy raised to revere the coastal rainforest as a realm of the divine, will be a different person from a child taught to believe that such forest is destined to be logged. (p.123)

\section{What Are Trees Trying To Tell Us? What Do We Need To Listen To?}

The current peak of our technological era is recycling towards greater and greater interconnectivity, moving away from crude mechanistic understandings of the world and the universe we inhabit. We are beginning to mirror the complexity and sophistication of the ecological systems in which we are embedded. The World Wide Web is beginning to approximate and replicate the Wood Wide Web, the fine fibre optic mycorrhizal highways that link our forests. The term "recycling" mirrors Sandoval, Lagunas, Montelongo and Diaz's (2016) use of the concepts of "re-cycling, re-creating and re-membering" (p. 28) as a part of ancestral knowledge systems where knowledge (including technological innovation) is intergenerational, cyclic, and shared, compared to Western notions of intellectual property and individual ownership.

Despite the technological genius of our modern era, we stand on the brink of the greatest ecological catastrophe of our age - global warming, increasing violence, and the dislocation of immense numbers of people fleeing war, famine, poverty, ethnocide, and epistimicide. These "human" catastrophes are intimately linked to fragmented and mechanistic paradigms inherent in our technocratic societies; poverty, oppression, and global warming are directly linked to consumerism and the acquisition of wealth including the structures of domination which support these fragmented systems and ways of thinking and being. It is important to note, as Davis (2009) stated, that it is neither change nor technology per se that threatens the integrity of culture and the ecological equilibrium, "It is power - the crude face of domination" (p.167).

If we accept that our external world and our internal experience are interdependent and dynamic processes, and, that our internal experience impacts critically on our environment, then we can start to think about ourselves as an organism within a highly complex ecological system. As Davis (2009) pointed out, this is a hopeful scenario, because if we are agents of destruction we can also be the catalyst for change; we have the capacity to consciously selfreflect and so therefore we have the potential to begin changing the current direction of our destructive trajectory.

What Matariki offers us is a way of remembering that the predominant Western 
conceptualisation of the world based on capital and neoliberal ideology is only one possible way of structuring our societies. Indigenous cultures remind us that there are numerous other options, other possibilities, other ways of conceptualising, organising, and understanding the world we live in, that global destruction is not inevitable. As Matua Haare Williams reminded me, "Matariki offers much more than a night sky, it is not merely to view the moon or the cosmos of stars but to remember a universe that makes a connection through whakapapa" (Williams, 2016, personal communication).

We have already begun listening to the stars, now we need to remember our roots and once again begin listening to trees.

\section{KOHA}

Our

Nanny Wai

sang

to orchard trees

calling each

by name

We didn't really know

Why

You give little

when you give things

give of yourselves

like trees

that's living

learn from trees

"Trees give their best

for trees

to hold back is to

die

With Earth

for Mother

Sky

for Father

they hold back

nothing!” 


\section{WIREMU WOODARD}

The year

Nanny Wai went

the trees grew old

and died

we didn't really know

why

Koha - reciprocity to give, to receive and to return

Haare Williams, May 1982

He mihi aroha tēnei mo te tautoko aroha a Dr. Michael Yellow Bird rāua ko Haare Williams, mo ā rāua wāhanga tautoko. He tangata tino humarie.

With humble thanks to Dr. Michael Yellow Bird and Matua Haare Williams for their generosity and wisdom; two men of great heart soul.

Nā reirā

Tūturu whakamaua kia tina

Tina!

Haumi è

Hui è

Tāiki ē!

\section{References}

Arabena, K. (2015). Becoming Indigenous to the universe: Reflections on living systems, indigeneity and citizenship. Sydney, Australia: Australian Scholarly Publishing.

Babikova, Z., Gilbert, L., Bruce, T. J. A., Birkett, M., Caulfield, J. C., Woodcock, C., Pickett, J.A., \& Johnson, D. (2013). Underground signals carried through common mycelial networks warn neighbouring plants of aphid attack. Ecology Letters, 16 (7), 835-843.

Briggs, D. (2009). Plant microevolution and conservation in human-influenced ecosystems. Cambridge, England: Cambridge University Press.

Cossins, D. (2014, January 1). Plant talk. The Scientist. Retrieved from http://www.the-scientist. com/?articles.view/articleNo/38727/title/Palnt-Talk/

Cumo, C. (2016). Plants and people. Origin and development of human plant science relationships. Boca Raton, FL: CRC Press.

Dalal, F. (2002). Race, colour and the processes of racialization. New York, NY: Routledge.

Davis, W. (2003, February). Wade Davis: Dreams from endangered cultures [Video file]. Retrieved from http://www.ted.com/talks/wade_davis_on_endangered_cultures?language=en 


\section{Korero RAKAU}

Davis, W. (2009). The wayfinders: Why Indigenous wisdom matters in the modern world. Toronto, Canada: Anansi Press.

Elias, N. (1976). Introduction. In N. Elias \& J. Scotson (Eds.), The established and the outsiders (pp. 1-39). London, England: Sage.

Elias, N. (2010). The society of individuals. Dublin, Ireland: University College Dublin Press.

Erikson, E. (1966). The concept of identity in race relations. New York, NY: W. W. Norton.

Fanon, F. (1982). Black skin, white masks. New York, NY: Grove Press.

Fonagy, P. (2001). Attachment theory and psychoanalysis. London, England: Karnac.

Foulkes, S. H. (1948). Introduction to group analytic psychotherapy. London, England: Karnac Books,

Gaines, A. D, \& Davis-Floyd, R.D. (2004). Biomedicine. In M. Ember \& C. Ember (Eds.),

Encyclopaedia of Medical Anthropology (pp. 95-109). Dordrecht, The Netherlands: Kluwer Academic Publishers.

Holmes, J. (1993). John Bowlby and attachment theory. London, England: Routledge.

Hume, D. (1748). An inquiry concerning human understanding. Oxford, England: Oxford University Press.

King, J. (2003). 'Whaia te Reo: Pursuing the language': How metaphors describe our relationships with Indigenous languages. In J. Reyhner, O. Trujillo, R. L. Carrasco \& L. Lockard (Eds.), Nurturing Native Languages (pp.105-124). Flagstaff, AZ: Northern Arizona University.

Klein,T., Siegwolf, R. T. W., \& Körner, C. (2016). Below ground carbon trade among tall trees in a temperate forest. Science, 352 (6283), 342-344. doi: 10.1126/science.aad6188

Lackoff, G., \& Johnson, M. (1980). Metaphors we live by. Chicago, IL: University of Chicago.

McGrane, S. (2016, January 29). German forest ranger finds that trees have social networks, too. The New York Times. Retrieved from http://nyti.ms/1Kf8YDS

Ngata, A. P. (2004-2007). Ngā mōteatea : he maramara rere nō ngā waka maha / he mea kohikohi nā Sir Apirana Ngata = The songs : scattered pieces from many canoe areas / collected by Sir Apirana Ngata. Auckland, Aotearoa New Zealand: Auckland University Press.

Sandoval, C. D. M., Lagunas, R. M., Montelongo, L. T., \& Díaz, M. J. (2016). Ancestral knowledge systems: A conceptual framework for decolonizing research in social science. AlterNative: An International Journal of Indigenous Peoples, 12(01), 18-31. doi: 10.20507/AlterNative.2016.12.1.2

Schwartz, J. H., \& Tattersall, I. (2005). The Human Fossil Record, craniodental Morphology of Genus Homo (Africa and Asia). Hoboken, NJ: John Wiley \& Sons.

Tattersall, I., DeSalle, R., \& Wynne, P. (2007). Bones, brains and DNA: The human genome and human evolution. Piermont, NY: Bunker Hill Publishers.

Van der Merwe, N. J. (2005). CO2, grasses and human evolution. In J. R. Ehleringer, T. E. Cerling \& M. D. Dearing (Eds.), A history of atmospheric $\mathrm{CO}_{2}$ and its effects on plants, animals, and ecosystems (pp. 293-329). New York, NY: Springer.

Wells, S. (2002). The journey of man: A genetic odyssey. Princeton, NJ: Princeton University Press.

Wolenberg, P. (2016). The hidden life of trees: What they feel, how they communicate - discoveries from a secret world. Vancouver B.C., Canada: Greystone Books.

Yellow Bird. (2016, June) Neurodecolonization: Examining the connections between mindfulness practices and traditional Indigenous knowledge and contemplative practices. Distinguished visitor seminar held at the University of Auckland, Faculty of Education and Social Work. 


\section{WIREMU WOODARD}

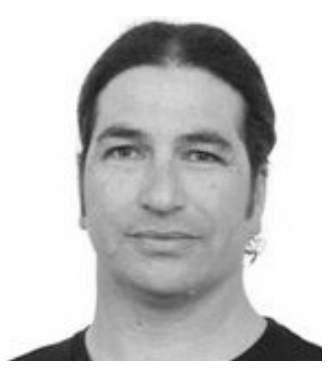

Wiremu Woodard is an Indigenous therapist, father of four, activist, environmentalist, sometimes contemporary dancer, and artist. Wiremu is committed to reducing health disparities for Māori and promoting social justice. He is a lecturer in the discipline of psychotherapy, and teaches on both psychotherapy and counselling programmes at Auckland University of Technology. He also is a founding member of Waka Oranga - a group of dynamic Indigenous Māori practitioners committed to emancipatory freedom. Contact details: wiremu.woodard@ aut.ac.nz . 